\title{
Use of folic acid supplements, particularly by low-income and young women: a series of systematic reviews to inform public health policy in the UK
}

\author{
Lynn Stockley, ${ }^{1, *}$ and Vivien Lund ${ }^{2}$ \\ 'Lynn Stockley \& Associates, Timberland, Brockweir, Chepstow NP16 7NN, UK: ${ }^{2}$ Food Standards Agency, \\ Aviation House, 125 Kingsway, London WC2B 6NH, UK
}

Submitted 22 March 2007: Accepted 9 August 2007: First published online 6 May 2008

\begin{abstract}
Objective: To provide a basis for making recommendations on the potential to improve use of folic acid supplements in the UK, particularly among low-income and young women.

Design: Systematic reviews of relevant research from 1989 to May 2006 in Europe, the USA, Canada, Australia and New Zealand.

Results: Twenty-six systematic reviews and/or meta-analyses were identified from the wider public health literature, and eighteen studies on the effectiveness of preconception interventions were included. Ninety studies were identified which were directly relevant to folic acid supplement intake. There were factors that are particularly associated with lower rates of use of folic acid supplements. One of the most important of these is the link with unintended pregnancy, followed by age, socio-economic and ethnic group. Integrated campaigns can increase the use of folic acid supplements to some extent. Research trials indicated that: (i) printed resources and the mass media used in isolation are not effective in the longer term; and (ii) health-care-based initiatives can be effective and are more likely to be successful if they include making supplements easily available.

Conclusions: Campaigns and interventions have the potential to exacerbate socioeconomic inequalities in folic acid use. One way of addressing this is to include elements that specifically target vulnerable women. To achieve and maintain an effect, they need to be based on good health promotion practice and to be sustained over a long period. However, even high-quality campaigns that increase use result in under half of women in the target group taking supplements.
\end{abstract}

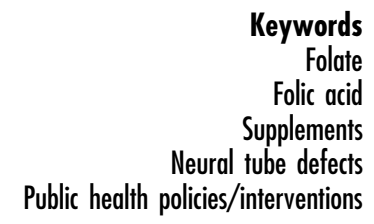

The overall aim of the work described in the present paper was to use a systematic approach to carry out literature reviews of research that has been done on influencing low-income groups, particularly girls/young women, to change their behaviour in relation to health. The intention was to provide a basis for making evidencebased recommendations on the potential to improve use of folic acid supplements in the UK.

This was achieved by carrying out three complementary reviews. The first two of these provided a basis for the main (third) review. They were intended to assess whether there are findings from the wider public health literature (rather than work focusing specifically on folic acid) that might inform the development of effective interventions to increase use of folic acid supplements. Review 1 identified published systematic reviews or meta-analyses of initiatives that required 'positive precautionary action' by women. Review 2 identified research relevant to the effectiveness of different approaches to preconception interventions on behaviour. Review 3 formed the main part of the work, and focused specifically on quantitative or qualitative research aimed at encouraging women, particularly girls/young women and those from low-income groups, to take folic acid in the periconceptional period.

\section{Background}

Neural tube defects (NTD) arise early in pregnancy, leading to malformation of the brain and spinal tube. There is considerable variation in the risk of fetuses being affected by NTD, associated for example with genetic factors (people of Northern European and Asian origin have a higher risk), diet, socio-economic group and maternal health.

In European countries, the incidence of NTD-affected births decreased during the 1980s but levelled off during 
the 1990s. The reasons for the decrease are not fully understood but seem to include improvements in screening and environmental changes.

The preventive role of folic acid in relation to NTD was highlighted by research carried out in the $1980 \mathrm{~s}^{(1,2)}$. The publication of these findings led to recommendations that, to reduce the risk of occurrence of NTD, all women of childbearing age should increase daily folic acid intake by $400 \mu \mathrm{g}$ prior to conception and during the first twelve weeks of pregnancy ${ }^{(3)}$. This was subsequently reinforced by the UK's Scientific Advisory Committee on Nutrition ${ }^{(4)}$. Similar advice was published in countries around the world. It is difficult to obtain $400 \mu \mathrm{g}$ of folic acid daily from foods alone, and so the general recommendation for implementation of this advice was through a combination of dietary change, encouraging periconceptional folic acid supplement use, and voluntary fortification of specified foods.

The USA, closely followed by Canada, was the first country to do this by introducing mandatory fortification of all cereal grain products in 1996. This move reflected concern about the difficulty of encouraging women to take supplements before they know they are pregnant, which is a problem that becomes magnified in countries with high rates of unplanned pregnancies. Supplements are also less likely to be taken by some groups of women, including those who are on lower incomes or who are younger.

Across the world more than forty countries have now introduced mandatory folic acid food fortification, including many South American and African countries ${ }^{(5)}$. Australia and New Zealand are currently exploring the option of mandatory fortification ${ }^{(6)}$, and it has been recommended in Ireland ${ }^{(5)}$. The UK is also currently considering the issue ${ }^{(7)}$. The present work was carried out as part of the UK exercise, to assess whether there is potential to improve use of folic acid supplements in the UK.

\section{Method}

For all three reviews, an initial screen of titles and abstracts was done online to ensure that included papers broadly reflected the initial inclusion and exclusion criteria. When a title and abstract could not be rejected with certainty, the abstract was downloaded for more detailed scrutiny using the initial inclusion and exclusion criteria. The criteria were then refined. Where papers could not be clearly rejected using the abstracts, the full text of the article was obtained for further scrutiny. References were downloaded to Endnote software and were de-duplicated.

A data extraction form was designed to standardise data collection for each review and to provide summaries of each piece of included information.

In the analyses, studies were organised by research design. The original intention was to prioritise studies that were clearly based on a theoretical model of behavioural change. However, as described in the Results section, very few such studies were identified.

Details of the databases searched, search terms and initial inclusion and exclusion criteria are provided in the Appendix. The detailed inclusion and exclusion criteria, and the list of data extraction fields, are available from the authors.

\section{Results}

Detailed information on the numbers of papers identified at each stage, and lists of excluded papers with reasons for exclusion, can be obtained from the authors.

\section{Preliminary reviews (Reviews 1 and 2)}

Twenty-six systematic reviews and/or meta-analyses were finally included in Review 1.

The range of topic areas included as having potential relevance to use of folic acid supplements was: (i) breastfeeding initiation $(n 6)^{(8-13)}$; (ii) communication in maternity care $(n 1)^{(14)}$; (iii) promoting increased fruit and vegetable consumption $(n 1)^{(15)}$; (iv) promoting physical activity $(n 5)^{(16-20)}$; (v) screening $(n 4)^{(21-24)}$; (vi) minimising the risk of unintended teenage pregnancy $(n 7)^{(25-31)}$; (vii) UV protection $(n 1)^{(32)}$; and (viii) preconception care $(n 1)^{(33)}$.

The results which are most directly relevant to encouraging periconceptional use of folic acid supplements are given below.

The only systematic review identified in Review 1 on preconception care was used as a starting point for Review 2, which focused on identifying research relevant to the effectiveness of different approaches to preconception interventions on behaviour. Eighteen papers were finally included in Review 2, and the results are described in the section on Preconception care below.

\section{Breast-feeding initiation}

Breast-feeding initiation is relevant to the current review because there are some similarities with the decision to begin taking folic acid supplements. For example: there are relatively low breast-feeding initiation rates in women who are living on a low income and/or who are younger; and promotion of breast-feeding can begin before conception (e.g. in schools), although in reality most interventions begin in the antenatal period.

The most recent paper identified consisted of a systematic review and a meta-analysis ${ }^{(8)}$. It included only randomised controlled trials, and identified seven studies for inclusion. The meta-analysis was carried out on five of these studies. Overall the interventions were effective in increasing breast-feeding initiation; however, there was some variation in effectiveness between the different approaches. For example, one-to-one support from lactation 
consultants, in an intervention based on the participants' needs and interests and including follow-up, proved to be effective. On the other hand, breast-feeding promotion packs (non-commercial) were not effective among women of middle-higher income.

The same research group published an earlier systematic review of the same topic ${ }^{(11)}$ that differed in covering not only randomised controlled trials, but also other controlled studies and quasi-experimental studies. The types of intervention that were effective among women from different income and ethnic groups included: small informal health education classes; one-to-one health education; peer counselling; or a combination of these. Multifaceted interventions comprising a media campaign, together with a peer support programme and other activities, also resulted in increased initiation rates. The types of intervention that did not appear to be effective included: breast-feeding literature alone or in combination with more formal, non-interactive health education; social support from health professionals; programmes directed at health professionals increased knowledge, but did not change attitudes; and media campaigns alone had the potential to improve attitudes, but not behaviour.

The findings of the other four reviews identified cover similar material to the two described above.

\section{Screening}

One review covered prenatal screening ${ }^{(22)}$, and this focused specifically on the UK. The types of screening covered were for Down's syndrome, NTD, haemoglobin disorders and HIV. Only six studies reported data according to women's social class or education level and although none found any significant social inequalities in testing, some studies suggested that women of South Asian origin might be less likely to participate in screening.

The other three reviews identified all concentrated on cervical screening, and there was overlap between them. The most recent was a systematic review of the effectiveness of community-based strategies ${ }^{(21)}$. The most frequently used interventions were: mass-media campaigns, alone or combined with individual strategies; individual education using lay health educators; and letters of invitation. Improvements ranged from $61 \%$ for educational videos to $12 \%$ for a physician letter compared with a no intervention group. Of the four studies that used mass-media campaigns alone, only one was effective and that study targeted a specific subpopulation with language-specific material. All of the studies that combined mass-media campaigns with other strategies were effective. Letters of invitation were effective but required a centralised registry to identify eligible women.

\section{Minimising the risk of unintended teenage pregnancy}

This topic is particularly relevant to the issue of use of folic acid supplements. There are parallels in terms of the required behaviours being positive and precautionary and the at-risk population groups are similar. There is also a direct interaction between the two topics, since folic acid supplements are less likely to be taken by women who did not intend to become pregnant.

Three of the included studies were published in the UK by a research group from the Evidence for Policy and Practice Information and Co-ordinating Centre (EPPI Centre). The most recent of these ${ }^{(25)}$ covered all dates in electronic databases, all types of study including qualitative research and process evaluation, and studies including young people under 20 years of age. Six of the included intervention studies provided sound evidence of the value of two particular approaches: (i) early childhood interventions consisting of pre-school education, parenting support and social skills development; and (ii) youth development programmes combining community service and student learning, or providing a programme of academic and social development. A metaanalysis indicated that these approaches reduced the risk of pregnancy by $39 \%$. The next review from this research group ${ }^{(26)}$ looked at the role of incentive schemes in encouraging positive health and social behaviours in young people. The main findings were that: (i) the behaviours need to be logged and rewarded consistently; (ii) interventions need to be implemented properly and consistently; (iii) large-scale incentive-based schemes require staff with the necessary skills and commitment, and sound systems in place to support them; and (iv) the size or type of incentive on offer needs to be sufficient to motivate change in young people.

The third review from this group ${ }^{(31)}$ addressed the use of peer-delivered health promotion interventions. There were two relevant interventions and these were both in school settings. The conclusions from the first of these included the importance of focusing the intervention on one topic; incorporating it into a wider programme of sex education; and reflecting the principles of 'good practice' in health promotion, including empowerment and participation.

Of the remaining reviews identified, one described some specific studies that may be relevant to the use of folic acid supplements ${ }^{(27)}$. This review assessed the usefulness of counselling in a clinical setting to prevent unintended pregnancy and included all types of studies including those using qualitative methods. In one of the included studies, women who were more likely to take the contraceptive pill consistently took it at the same time each day, read and understood all of the package information, and took the pill at a routine time other than immediately before going to sleep.

\section{Preconception care}

The systematic review identified in Review 1 focused more on the effectiveness of preconception interventions in reducing the risk of diseases rather than the approaches used ${ }^{(33)}$. However, it provided a basis for a more 
in-depth exploration of literature on preconception care in Review 2.

The eighteen studies that were finally included in Review 2 were organised by research methodology and within that by country of publication.

Increasingly, policies and guidance for preconception care have been developed in countries around the world $^{(34-36)}$. The USA appears to be at the forefront of this. The Centers for Disease Control and Prevention ${ }^{(37)}$ published a detailed evaluation of the available evidence and recommendations in 2006, and forty-two States have performance measures which relate to preconception care.

There is some evidence that preconception care has a positive impact on health behaviours, and there are also indications that participation in preconceptional care may decrease the number of unplanned pregnancies.

Two prospective studies were identified. The first of these was carried out in the $\mathrm{USA}^{(38)}$ and reported that women who were offered a preconception health promotion programme were more likely to identify their pregnancies as intended than a group who did not take part in the programme. The authors concluded that preconception programmes could prove useful for promoting intendedness of pregnancy in low-income women. The other prospective study ${ }^{(39)}$ followed women who participated in the Hungarian periconceptional care programme over a 10-year period. The results indicated that the programme was effective in improving many aspects of periconceptional care, including reducing smoking and alcohol consumption, and increasing the use of folic acid-containing multivitamin supplements.

Cross-sectional studies from The Netherlands ${ }^{(40-42)}$ and one from the $\mathrm{UK}^{(43)}$ indicated that most women, doctors and other relevant health professionals support the idea of preconception care, although in practice it happens rarely. Lack of time and possibly motivation and prioritisation among health professionals appear to be important barriers. The one randomised controlled trial which was identified in this section $^{(44)}$ found that informing doctors and women about identified preconception risks did not encourage them to do more. However, a trial without a control group was identified ${ }^{(45)}$ which indicated that providing education and standardised forms was effective in increasing screening, although this did not affect staff knowledge and attitudes.

\section{Main review (Review 3)}

Ninety studies were finally included; these were organised by research methodology and within that by country of publication (Table 1).

\section{Systematic reviews}

The systematic review that is most relevant to the current work covered worldwide literature up until 2003, but differs from the current work in that it focused specifically on three aspects of folic acid supplement use ${ }^{(46)}$ : (i) the rate of use (i.e. not awareness) pre- and periconceptionally; (ii) the demographic characteristics associated with low rates of use; and (iii) folic acid use in relation to public awareness campaigns only. Review 3 conducted in the present work includes all types of research, including evaluations of campaigns. It also includes information on awareness of folic acid/folate recommendations.

A total of fifty-two studies were included in the review. The authors drew out a number of lessons for the future: family planning initiatives should promote folic acid supplement use; in view of the low rates of planned pregnancy in many countries, better approaches are needed to ensure that folic acid is taken as soon as possible after conception; the best public health programmes reach, at most, $50 \%$ of women; and some women may not receive or comprehend the folic acid message, particularly young, single women, those without a formal education and those who are recent immigrants.

The other systematic review that was identified ${ }^{(47)}$ focused specifically on state-wide programmes of folic acid education in the USA which used the social ecological model. This model is a multifaceted approach to health promotion, which includes environmental, behavioural and social policy changes that help individuals adopt healthy behaviours. Most state-wide folic acid campaigns did not incorporate all levels of the social ecological model, although most included interventions in at least two levels.

\section{Research trials on the effectiveness of different types of intervention}

There were five controlled trials in total. The main characteristics of these trials are shown in Table 2.

Watson et $a l^{(48,49)}$ reported a randomised community intervention trial from Australia, which assessed the effectiveness of using only a printed communication. Folate awareness increased in the intervention group, but was sustained only in women aged 35-44 years. The intervention was also less effective for socially disadvantaged women.

Three of the controlled trials from the USA focused on health sector interventions providing free supplements. Lawrence et $a l .{ }^{(50)}$ evaluated the effect of information and 'starter kits' of multivitamins being mailed to one group, while another group received the information through primary-care providers. There was a small but significant increase in the percentage of women using multivitamins in the direct mail group at the beginning of the intervention period, but this increase was not sustained after the interventions ended. However, in two trials, free folic acid supplements were provided either during routine gynaecological visits (Robbins et al. $)^{(51)}$ or in family planning clinics (Watkins et al. $)^{(52)}$. Both of these studies reported significant increases in reported consumption, 
Table 1 Review 3: work finally included, by study design and then by country

\begin{tabular}{|c|c|c|}
\hline Study design & Country & Study \\
\hline Systematic reviews & $\begin{array}{l}\text { Global } \\
\text { USA }\end{array}$ & $\begin{array}{l}\text { Ray et al. }(2004)^{(46)} \\
\text { Quinn et al. }(2005)^{(46)}\end{array}$ \\
\hline Expert reports/Consultations & $\begin{array}{l}\text { Australia and } \\
\text { New Zealand } \\
\text { Ireland } \\
\text { UK }\end{array}$ & $\begin{array}{l}\text { Food Standards Australia New Zealand }(2004)^{(6)} \\
\text { Food Safety Authority of Ireland (2006) } \\
\text { Folic Acid Roundtable } \\
(136)\end{array}$ \\
\hline Controlled trials & $\begin{array}{l}\text { Australia } \\
\text { USA }\end{array}$ & $\begin{array}{l}\text { Watson et al. }(2001)^{(132)} \text {; Watson et al. }(2002)^{(49)} \\
\text { Johnson et al. }(2002)^{(53)} \text {; Lawrence et al. }(2003)^{(50)} \text {; Robbins et al. }(2005)^{(51)} \text {; } \\
\quad \text { Watkins et al. }(2004)^{(52)}\end{array}$ \\
\hline Trials without a separate control group & $\begin{array}{l}\text { Australia } \\
\text { Netherlands } \\
\text { UK } \\
\text { USA }\end{array}$ & $\begin{array}{l}\text { Williams et al. }(2001)^{(61)} \\
\text { de Weerd et al. }(2002)^{(57)} \\
\text { Edwards \& Wyles (1999) } \\
\text { Chacko et al. }(2003)^{(58)} \text {; DiPietro \& Kier }(2001)^{(54)} \text {; Hauser et al. }(2004)^{(60)} \text {; } \\
\quad \text { Morgan et al. }(2004)^{(56)} ; \text { Quillin et al. }(2000)^{(55)}\end{array}$ \\
\hline Campaign/Programme evaluations & $\begin{array}{l}\text { Australia } \\
\text { Canada } \\
\text { Germany } \\
\text { Northern Ireland } \\
\text { Netherlands } \\
\text { UK } \\
\text { USA }\end{array}$ & $\begin{array}{l}\text { Chan et al. }(2001)^{(62)} \\
\text { Public Health Agency of Canada }(2003)^{(63)} \\
\text { Egen \& Hasford }(2003)^{(68)} \\
\text { Health Promotion Agency for Northern Ireland }(1999)^{(70)} \\
\text { de Walle et al. }(2002)^{(67)} ; \text { van der Pal-de Bruin et al. }(2003)^{(66)} \\
\text { Raats et al. }(1998)^{(64)} \\
\text { CDC (1999) })^{(69)}\end{array}$ \\
\hline \multirow{9}{*}{$\begin{array}{l}\text { Cost-effectiveness analysis } \\
\text { Cross-sectional surveys + prospective } \\
\text { cohort 'monitoring' (preceded by } \\
\text { an asterisk) }\end{array}$} & Netherlands & de Weerd et al. (2004) ${ }^{(137)}$ \\
\hline & $\begin{array}{l}\text { Australia } \\
\text { Canada }\end{array}$ & $\begin{array}{l}\left.\left.\text { Bower \& Stanley }(2004)^{(72)} \text {; Bower et al. }(2005)^{(73)} \text {; Watson et al. }(2006)^{(71)}\right) \text {, }\right)^{(78)} \\
\text { Einarson \& Koren }(2006)^{(74)} \text {; French et al. }(2003)^{(75)} \text {; Morin et al. }(2001)^{(79)} \text {; } \\
\quad \text { Morin et al. }(2002)^{(76)} \text {; Morin et al. }(2002)^{(77)} \text {; Neimanis et al. }(1999)^{(79)} \\
\quad \text { Tam et al. }(2005)^{(80)}\end{array}$ \\
\hline & Croatia & Gjergja et al. $(2006)^{(81)}$ \\
\hline & $\begin{array}{l}\text { Denmark } \\
\text { Ireland }\end{array}$ & $\begin{array}{l}\text { *Knudsen et al. }(2004)^{(82)} \\
\text { Oleary et al. }(2001)^{(84)} \text {; McDonnell et al. }(1999)^{(83)} \text {; Ward et al. }(2004)^{(85)}\end{array}$ \\
\hline & Netherlands & $\begin{array}{l}\text { Bakker et al. }(2003)^{(86)} \text {; de Jong-van den Berg et al. }(1998)^{(87)} \\
\text { de Walle et al. }(2002)^{(67)}\end{array}$ \\
\hline & $\begin{array}{l}\text { New Zealand } \\
\text { Norway } \\
\text { Poland } \\
\text { Spain }\end{array}$ & $\begin{array}{l}\text { Allen et al. }(2000)^{(88)} \text {; Schader \& Corwin }(1999)^{(89)} \\
\text { Braekke \& Staff }(2003)^{(90)} \text {; Daltveit et al. }(2004)^{(91)} \text {; Vollset \& Lande }(2000)^{(92)} \\
\text { Szumska \& Mazur (1999) } \\
\text { Cano-Serral et al. (2006) }{ }^{(94)} \text {; Coll et al. }(2004)^{(95)} \text {; Garcia Carballo et al. } \\
\quad(2003)^{(96)}\end{array}$ \\
\hline & Sweden & Lundqvist et al. $(2004)^{(130)}$ \\
\hline & UK & $\begin{array}{l}\text { Blake et al. }(2003)^{(97)} \text {; Glasgow Perinatal Effectiveness Committee } \\
\quad(1998)^{(98)} ; \text { Haslam et al. (2003) }{ }^{(99)} \text {; Howell et al. }(2001)^{(100)} \text {; ICM } \\
\text { Research }(2004)^{(101)} \text {; Johnson }(2000)^{(102)} \text {; Langley-Evans \& Langley- } \\
\text { Evans }(2002)^{(103)} \text {; Mathews et al. }(1998)^{(104)} \text {; Neill et al. }(1999)^{(105)} ; \\
\quad{ }^{*} \text { Relton et al. }(2005)^{(106)} \text {; Rogers \& Emmett }(1998)^{(107)} \text {; Sen et al. }(2001)^{(108)} \text {; } \\
\text { Sillender }(2000)^{(109)} \text {; Sillender \& Pring }(2000)^{(110)} \text {; Wald (personal } \\
\text { communication, 2005) }\end{array}$ \\
\hline & USA & 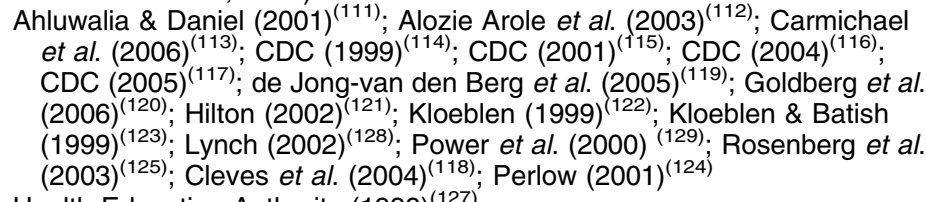 \\
\hline Qualitative research & UK & Health Education Authority $(1999)^{(127)}$ \\
\hline Case studies & $\begin{array}{l}\text { Europe }(18 \\
\text { countries) }\end{array}$ & Eurocat $(2005)^{(126)}$ \\
\hline
\end{tabular}

CDC, Centers for Disease Control and Prevention.

and in the Robbins study ${ }^{(51)}$ weekly folic acid intake increased in the intervention group by $68 \%$ compared with $20 \%$ in the control group. Those who were most influenced by the intervention were black and lowerincome and not planning pregnancies.

The remaining controlled trial from the USA, reported by Johnson et al. ${ }^{(53)}$, indicated that a short educational intervention was effective in increasing knowledge in high-school students.
There were eight trials which did not have a control group. The main characteristics of these trials are shown in Table 3.

Of the eight trials, three were small studies with students and are not described further here (DiPietro and Kier, Quillin et al., Morgan et al. $)^{(54-56)}$.

Two of the remaining trials described preconception interventions led by health professionals. De Weerd et al. ${ }^{(57)}$ in The Netherlands assessed whether preconception 
Table 2 Review 3: characteristics of controlled trials organised in alphabetical order by first author

\begin{tabular}{|c|c|c|c|c|c|c|}
\hline Study/country & Allocation to groups & $\begin{array}{l}\text { No. and type of } \\
\text { participants }\end{array}$ & Groups & Intervention and duration & Follow-up & Evaluation measures \\
\hline $\begin{array}{l}\text { Johnson et al. } \\
\qquad(2002)^{(53)} / \text { USA }\end{array}$ & $\begin{array}{l}\text { Allocation by school } \\
\text { ( } n 6 \text { in } 3 \text { areas) }\end{array}$ & $\begin{array}{l}345 \text { male and } \\
\text { female students }\end{array}$ & $\begin{array}{l}\text { Intervention } v \text {. control with } \\
\text { delayed treatment }\end{array}$ & $\begin{array}{l}\text { Seminar and slide presentation, } \\
\text { delivered in school time }\end{array}$ & $\begin{array}{l}16-26 \mathrm{~d} \text { after } \\
\text { intervention }\end{array}$ & $\begin{array}{l}\text { Pre-test and post-test self- } \\
\text { completed questionnaire }\end{array}$ \\
\hline $\begin{array}{l}\text { Lawrence et al. } \\
\qquad(2003)^{(50)} / \text { USA }\end{array}$ & $\begin{array}{l}\text { Time-series design with } \\
\text { a non-equivalent } \\
\text { control group }\end{array}$ & $\begin{array}{l}3438 \text { women, } 18-39 \\
\text { years old, of } \\
\text { childbearing age }\end{array}$ & $\begin{array}{l}\text { Intervention v. education } \\
\text { intervention from } \\
\text { primary-care providers }\end{array}$ & $\begin{array}{l}100 \text { multivitamins by post plus } \\
\text { printed educational material } \\
\text { at health-care visits }\end{array}$ & $\begin{array}{l}18 \text { months after } \\
\text { intervention }\end{array}$ & Telephone interviews \\
\hline $\begin{array}{l}\text { Robbins et al. } \\
\qquad(2005)^{(51)} / \text { USA }\end{array}$ & Randomised allocation & $\begin{array}{l}322 \text { non-pregnant } \\
\text { women, 18-45 } \\
\text { years }\end{array}$ & $\begin{array}{l}\text { Intervention } v \text {. control with } \\
\text { counselling about other } \\
\text { health behaviours plus } \\
\text { folic acid leaflet }\end{array}$ & $\begin{array}{l}\text { Folic acid counselling, reminder } \\
\text { phone call plus } 30 \text { folic acid } \\
\text { tablets }\end{array}$ & 2 months & Self-reported folic acid use \\
\hline $\begin{array}{l}\text { Watkins et al. } \\
(2004)^{(52)} / \text { USA }\end{array}$ & $\begin{array}{l}\text { Allocation by family } \\
\text { planning clinic }(n 6)\end{array}$ & $\begin{array}{l}165 \text { women aged } \\
18-45 \text { years }\end{array}$ & $\begin{array}{l}\text { Two intervention groups } \\
v . \text { control - educational } \\
\text { materials only }\end{array}$ & $\begin{array}{l}\text { Folic acid pills or fortified cereal } \\
\text { provided plus educational } \\
\text { materials }\end{array}$ & No & $\begin{array}{l}\text { Self-reported folic acid } \\
\text { consumption and serum } \\
\text { folate }\end{array}$ \\
\hline $\begin{array}{l}\text { Watson et al. } \\
(2001)^{(132)} \text { and } \\
\text { Watson et al. } \\
(2002)^{(49)} / \text { Australia }\end{array}$ & $\begin{array}{l}\text { Allocation by Local } \\
\text { Government Area } \\
(n 6)\end{array}$ & $\begin{array}{l}1197 \text { women of } \\
\text { childbearing age }\end{array}$ & Intervention $v$. control & $\begin{array}{l}\text { Selection of printed material } \\
\text { distributed through community } \\
\text { over a 2-month period }\end{array}$ & $\begin{array}{l}2 \text { months and } 30 \\
\text { months after } \\
\text { intervention }\end{array}$ & Telephone interviews \\
\hline
\end{tabular}

Table 3 Review 3: characteristics of trials without a control group organised in alphabetical order by first author

\begin{tabular}{|c|c|c|c|c|c|}
\hline Study & Design & No. and type of participants & Intervention and duration & Follow-up & Evaluation measures \\
\hline Chacko et al. (2003) ${ }^{(58)}$ & $\begin{array}{l}\text { Baseline survey of all } \\
\text { women; follow-up survey } \\
\text { on } 25 \% \text { random sample }\end{array}$ & $\begin{array}{l}387 \text { low-income, young, mostly } \\
\text { Hispanic and black, non-pregnant } \\
\text { women aged } 13-22 \text { years, } \\
\text { recruited at hospital clinics }\end{array}$ & $\begin{array}{l}\text { Interested women given 3-month } \\
\text { supply of multivitamins }\end{array}$ & 3 months & Self-completion questionnaire \\
\hline de Weerd et al. $(2002)^{(57)}$ & Pre and post measures & 111 women & $\begin{array}{l}\text { Preconceptional consultation, } \\
\text { recruited at preconception } \\
\text { counselling }\end{array}$ & 4 months & $\begin{array}{l}\text { Self-reported usage of folic acid } \\
\text { supplements and serum folate }\end{array}$ \\
\hline DiPietro \& Kier (2001) $)^{(54)}$ & Pre and post measures & $\begin{array}{l}142 \text { young women voluntarily } \\
\text { attending a seminar }\end{array}$ & $\begin{array}{l}\text { Seminar, consisting of a } 45 \mathrm{~min} \\
\text { Powerpoint presentation }\end{array}$ & 4 weeks & Self-completion questionnaire \\
\hline Edwards \& Wyles (1999) ${ }^{(59)}$ & $\begin{array}{l}\text { Pre and post measures at } \\
\text { each training session }\end{array}$ & $\begin{array}{l}189 \text { community health } \\
\text { professionals }\end{array}$ & $1 \mathrm{~h}$ training sessions & None & $\begin{array}{l}\text { Self-completion questionnaires and } \\
\text { feedback }\end{array}$ \\
\hline Hauser et al. $(2004)^{(60)}$ & Pre and post measures & $\begin{array}{c}5000+\text { health professionals } \\
(29-32 \% \text { response rate })\end{array}$ & State-wide education campaign & None & Mailed questionnaire \\
\hline Morgan et al. (2004) ${ }^{(56)}$ & Pre and post measures & $\begin{array}{l}76 \text { students on Women's Health } \\
\text { course }\end{array}$ & Viewing $C D$ & 2 weeks & Self-completion questionnaires \\
\hline Quillin et al. $(2000)^{(55)}$ & $\begin{array}{l}\text { Pre- and post-test } \\
\text { (beginning and end of } \\
\text { a } 45 \mathrm{~min} \text { session) }\end{array}$ & 71 female students & $\begin{array}{l}5 \text { min educational slide } \\
\text { presentation }\end{array}$ & No & Self-completion questionnaires \\
\hline Williams et al. $(2001)^{(61)}$ & Pre- and post-test & $500+$ women aged $18-44$ years & $\begin{array}{l}\text { 12-month multimedia folate } \\
\text { education campaign; first half } \\
\text { without health claims, second } \\
\text { half with health claims }\end{array}$ & No & $\begin{array}{l}\text { Telephone surveys at baseline, end } \\
\text { of first half of campaign, and end } \\
\text { of second half of campaign }\end{array}$ \\
\hline
\end{tabular}


counselling improves the folate status of women planning pregnancy. This showed significant increases four months after the intervention, with higher figures in those women who were not already taking a supplement. In the USA a trained health educator implemented a folic acid promotion programme at three clinics (Chacko et al.) ${ }^{(58)}$. When a young woman indicated interest in taking a daily multivitamin, she was given a 3-month supply of multivitamin tablets. Daily multivitamin intake increased significantly from $9 \%$ to $67 \%$ at 3 months after the intervention.

Another two trials focused on approaches to increase health professionals' knowledge of folic acid advice. Edwards and Wyles ${ }^{(59)}$ in the UK evaluated the effectiveness of training sessions. Before the training sessions $42 \%$ of the health professionals thought that women could eat enough folic acid from food alone, and after the training this had fallen to just $1 \%$. In Florida, Hauser et al. ${ }^{(60)}$ assessed the effects of a state-wide educational initiative on health professionals' knowledge and practice. The initiative included articles in professional publications, presentations at continuing medical education courses, direct mailings, and educational booths at professional meetings. This resulted in a significant increase in knowledge and the percentage of health-care providers who recommended periconceptional use of folic acid.

The final trial described here measured the impact of a 12-month multimedia folate education campaign, with and without the use of health claims (Williams et al.) ${ }^{(61)}$. In the first six months of the campaign no health claims were made on folate-rich food, but in the second half of the campaign health claims were introduced. Awareness of the recommendation to take folate before pregnancy rose by $8 \%$ in the first six months of the campaign (without health claims) and by $22 \%$ in the second half (when health claims were incorporated on some food labels and in television advertisements and publications). It seems that including a specific health claim explaining the role of folate in preventing birth defects may increase the impact of a folate education campaign. This was in the context of foods rather than supplements, but the finding is also potentially relevant to the sales of supplements.

\section{Integrated national or regional campaigns}

Four integrated campaigns were identified which appear to have been successful in increasing intake of folic acid supplements to some extent. These four campaigns were carried out in South Australia, Canada, the UK and The Netherlands. In Australia ${ }^{(62)}$ a short campaign with a fairly limited budget covered both health professionals and women of childbearing age. The proportions of women taking periconceptional folic acid supplements increased significantly, and folic acid tablet sales doubled. However, there was no evidence that the effects would be sustained. In Canada ${ }^{(63)}$ a range of national and local educational initiatives were undertaken. Evaluation at three sites was carried out prior to mandatory fortification and for 2 years after the introduction of fortification. There were increases in the use of folic acid-containing supplements in Newfoundland, but not Ontario. In England ${ }^{(64)}$, the percentages of pregnant women and new mothers claiming to have taken folic acid before conception rose from $24 \%$ to $38 \%$. However, the authors of the evaluation report drew attention to the short duration of the campaign, particularly when compared with sustained health initiatives around smoking and HIV. Their concerns appear to have been justified, because a later study indicated a decline of about $10 \%$ in supplement intake 5 years after the campaign finished (NJ Wald, personal communication, 2005). In the Netherlands ${ }^{(65,66)}$ a national campaign included advertisements in newspapers and women's magazines, television and radio commercials, posters in the waiting rooms of general practitioners, midwives and gynaecologists, and information for women wishing to conceive available free from the pharmacist. An additional local campaign was targeted at women in lower socioeconomic groups. Periconceptional folic acid use increased from $16 \cdot 8 \%$ to $48 \cdot 6 \%$, but socio-economic differences in supplement use remained and persisted in a study carried out 3 years after the campaign ${ }^{(67)}$. Socioeconomic differences widened in the national campaign, but remained similar where the additional local campaign was implemented.

Two other campaigns were reported, from Germany ${ }^{(68)}$ and south-west Virginia ${ }^{(69)}$, where the effects of the interventions were limited, in particular with respect to socio-economic differences and knowledge about the appropriate timing for supplement use.

The final campaign identified, from Northern Ireland ${ }^{(70)}$, included data on awareness of the folic acid recommendations, but not on reported supplement use.

Cross-sectional and prospective cohort 'monitoring' surveys: awareness and intake of folic acid, and sources of information on folic acid

Fifty-six cross-sectional and two prospective cohort 'monitoring' surveys were identified; they are listed in Table 1.

Fifty-five of these covered various aspects of awareness of the folic acid/folate message, use of supplements and sources of information. The two main sampling approaches used were either to collect information among women of childbearing age or to collective retrospective information from pregnant women or new mothers. The main comparable findings are summarised in Table 4 by country. The source papers were those listed in Table 1: Australia ${ }^{(71-73)}$; Canada ${ }^{(74-80)}$; Croatia $^{(81)}$; Denmark ${ }^{(82)}$; Ireland ${ }^{(83-85)}$; The Netherlands ${ }^{(67,86,87)}$; New Zealand ${ }^{(88,89)}$; Norway ${ }^{(90-92)}$; Poland ${ }^{(93)}$; Spain ${ }^{(94-96)}$; the UK (NJ Wald, personal communication, 2005) ${ }^{(97-110)}$; and the USA ${ }^{(111-125)}$.

Although there is a great deal of data about awareness and knowledge of folate and folic acid supplements, 
Table 4 Comparable levels of awareness and use of folic acid, and sources of folic acid information, by country

\begin{tabular}{|c|c|c|c|}
\hline Country & $\begin{array}{l}\text { Awareness of folic acid/folate message } \\
\text { in pregnant women/new mothers }(\%)\end{array}$ & $\begin{array}{l}\text { Periconceptional } \\
\text { folic acid use (\%) }\end{array}$ & $\begin{array}{l}\text { Sources of information (\% of women citing as source of } \\
\text { information) }\end{array}$ \\
\hline Australia & 60 & $28-46$ & General practitioner or obstetrician (53), family or friends (45) \\
\hline Canada & $63-76$ & $40 / 21 \dagger$ & $\begin{array}{l}\text { Health professionals, magazines/newspapers, doctors, } \\
\text { television/radio }\end{array}$ \\
\hline Croatia & 72 & 14 & Media, health professionals, friends \\
\hline Denmark & NA & 22 & NA \\
\hline Ireland & 67 & $16-24$ & $\begin{array}{l}\text { Less-affluent women referred to their general practitioner } \\
\text { more as a source of advice; folic acid supplements were } \\
\text { not 'visible' enough when women wanted to find them }\end{array}$ \\
\hline Netherlands & $41-63$ & 36 & NA \\
\hline New Zealand & 63 & $35 / 3+$ & $\begin{array}{l}\text { General practitioners (48), media advertising (magazine or } \\
\text { health pamphlet or television promotion) }(20)\end{array}$ \\
\hline Norway & $17-46^{*}$ & $10 / 47 \ddagger$ & NA \\
\hline Poland & $15^{*}$ & 13 & General practitioners (43), magazines (42) \\
\hline Spain & 86 & 7 & \\
\hline UK & $66-81$ & $21-48$ & General practitioner $>$ midwife $>$ family/friends \\
\hline USA & 73 & $<20-53$ & $\begin{array}{l}\text { Magazine or newspaper articles ( } 31) \text {, radio or television, } \\
\text { health-care providers }\end{array}$ \\
\hline
\end{tabular}

NA, not available.

*Among women of childbearing age.

tAmong women with planned pregnancies/unplanned pregnancies.

¥Percentage in 1998/2000.

much of it is not directly comparable between studies. For example, some studies have just assessed familiarity with the term 'folic acid', some have asked about knowledge in relation to NTD or pregnancy, whereas others have assessed whether women know about the advice on when to take supplements. So, although these data can be invaluable for individual monitoring exercises, they are of restricted use when comparing results from different studies.

Data on supplement use (as recommended) are far more useful for this purpose, and some of the crosssectional surveys described here indicate that use (as recommended) reported by pregnant women and new mothers ranged from $7 \%$ (in Croatia) to 53\% (one study from the USA). However, most countries reported levels between 25\% and 35\%. Much lower levels are reported when data were collected from samples of women of childbearing age. New Zealand reported levels as low as 3\%. Case studies described by Eurocat in $2005^{(126)}$ indicated that similar levels are reported from France, Spain, Germany and Italy.

The works described in this section consistently indicated some factors that were particularly associated with lower awareness, knowledge, and rates of folic acid supplement use.

One of the most important of these is the link with unintended pregnancy. The rates of unintended pregnancy vary considerably within and between populations. In terms of variation between countries, some such as Poland report very low levels of planned pregnancy (10-20\%), some such as the UK and USA are intermediate (about 50\%), and others including Croatia and The Netherlands have very high rates of planned pregnancy (75-80\%).
Other factors that were identified as being associated with lower awareness and use included: lower household income; lower educational attainment; being a lone parent, unemployed, from a lower socio-economic group, younger or from particular racial/ethnic groups; lacking awareness/knowledge of the potential benefits and not being convinced of efficacy; and having a less healthy lifestyle.

Only one qualitative study was included ${ }^{(127)}$. This was from the UK and provided additional insights into the influences on young women, women in low-income groups, and those with poor educational backgrounds. The most relevant findings included: a fatalistic view of becoming pregnant; the importance of advice from mothers and friends compared with health professionals; and the difficulty in actively making contact with women in these groups.

The most common sources of information for women mentioned in these cross-sectional surveys tended to be mass-media advertising, magazines, newspaper articles, and family and friends. However, although health professionals were usually cited less frequently, their advice was regarded as more credible. Generally, family doctors seemed to be a more frequent source of advice than other health professionals, including midwives. In the UK, one of the trials mentioned earlier ${ }^{(59)}$ also indicated that practice nurses appear to be the group who are asked most frequently about folic acid (82\%) compared with general practitioners (55\%) and dietitians (13\%). Pharmacies were mentioned very infrequently.

The remaining three cross-sectional studies provided some information on the knowledge, attitudes and practice of selected health professionals. One of the studies ${ }^{(128)}$ was a very small student study from the USA, 
which is not described further. A more powerful study of obstetricians and gynaecologists in the USA showed good levels of awareness of the relationship between folate and NTD, with a high proportion saying that they already advise non-pregnant patients about folate intake ${ }^{(129)}$. The final cross-sectional study was of midwives in Sweden; it indicated they played an important role, but could be more effective if supported by local routines, guidelines and training ${ }^{(130)}$.

\section{Discussion}

The reviews reported here used a systematic approach (i.e. a predefined, transparent and reproducible process to identify, select and analyse studies) to assessing the evidence base relevant to folic acid supplement use, particularly in younger and low-income women. In addition to the main review, two preliminary reviews were carried out to assess whether there are relevant findings from the wider public health literature. In total over 2200 papers were identified in the initial literature searches, and 134 of these were finally included.

It would have been possible in the main review to limit the number of papers included by excluding crosssectional, qualitative and case studies. However it was judged that, if this had been done, valuable insights into influences on folic acid intake would have been lost. Because there was such a large volume of papers, and the searching and analysis were carried out by a single reviewer (i.e. cross-checking was not possible), no standardised quality assessment was carried out. However, the key characteristics commonly used to assess the quality of studies are given for control group and noncontrol group trials included in the main review. Small studies with a student population are not described in the text, and this has been noted where relevant. The large volume of papers also meant that reference lists from included studies were not searched.

Despite these methodological limitations, the present work represents the most up-to-date and comprehensive review of the issue. An earlier systematic review ${ }^{(46)}$ differed from the current work in that it focused on specific aspects of folic acid supplement use.

Another point to bear in mind when interpreting the findings for all three reviews is that there are important issues of transferability between topics and between countries. The other caveat is that many of the studies included only short-term follow-up, so there is very limited evidence on the sustainability of effects of interventions.

The health topics covered in Review 1 were very diverse. The approach adopted was to identify common features across each of the topic areas, in the expectation that since they were common, they were more likely to be transferable to folic acid interventions. Work has been carried out previously on the characteristics of effective health promotion interventions ${ }^{(131)}$, and many of these are reflected in the findings of the present review. The main points relevant to developing effective interventions, particularly for lower-income and young women, are that interventions should:

1. Include a 'package' of complementary components including different communication channels, locations and health promotion approaches, and be sustained over a long period;

2. Focus on high-risk groups;

3. Involve families if possible;

4. Incorporate folic acid information into school-based sex education;

5. Work with youth development programmes;

6. Consider peer-delivered approaches;

7. Provide practical support, e.g. easy access to supplements;

8. Encourage consistent use of supplements, e.g. by recommending that they are taken at the same time each day.

Review 2 found little research-based evidence on approaches to effective preconception care, although increasingly policies and guidance for preconception care have been developed in countries around the world. The health and social care structures in those countries with the most research and/or preconception polices or guidance are very different from those in the UK, which limits the applicability of much of the work that was identified. However, there is some evidence that preconception care can have a positive impact on health behaviours, including folic acid intake. There are also indications that participation in preconception care may decrease the number of unplanned pregnancies. The literature indicated that there are some barriers to effective preconception care, particularly: health professionals need adequate time, appropriate training and preconception care needs to be a recognised priority for them; and structural changes need to be incorporated into standard health care for more effective preconception care.

The research trials identified in Review 3 provide some indications of which types or aspects of interventions are more likely to be successful in increasing folic acid supplement intake.

Only two community-based trials were identified, both carried out in Australia. The first was a controlled trial $^{(49,132)}$, which concluded that using printed resources is less effective for women in lower socio-economic groups. This finding has been reported previously, for example by Freemantle et al. ${ }^{(133)}$. The second was a trial without a control group ${ }^{(61)}$ and this indicated that using a health claim may make it easier for women to identify relevant foods and supplements.

Community-based integrated campaigns have had some success in increasing awareness and usage of folic acid supplements. However, there are reservations about 
their effectiveness in the evaluations that have been carried out. For example, the effects are more evident in women from higher socio-economic groups, and are not sustained once the campaign has finished.

People within the health-care system seem to be well placed to provide advice on preconceptional folic acid, and appear to have potential to be effective in increasing intake. Nevertheless, the preliminary conclusions from the limited number of trials which have been carried out $^{(50-52,57-60)}$ are that advice needs to be embedded in a structure (e.g. preconceptional counselling) and delivered in a committed and relevant way by professionals with appropriate skills and knowledge. Providing free supplements to vulnerable women appears to be a promising approach. Currently in the UK folic acid supplements are available either by prescription or over the counter. There are emerging differences in criteria for cost of prescriptions and eligibility for free prescriptions in the four countries of the UK. For example in England, unless women are eligible for free prescriptions because of their age or income level, it may be cheaper to buy over-thecounter supplements. In contrast, in Wales all prescriptions were free in summer 2007.

The studies included in the main review used a variety of outcome measures, of which the most common were 'awareness' of the importance of folic acid supplements and 'use' of folic acid supplements. However, the terminology used in research in describing these outcomes is often ambiguous. For example, few studies distinguish between 'prompted' and 'unprompted' awareness, or describe clearly how it was assessed. Similarly, it was not always clear whether 'use' referred to taking supplements at some stage, or in pregnancy, or 'as recommended' (i.e. preconception and 12 weeks into pregnancy). Two general points emerge: (i) many studies only measured 'awareness' and not 'use'; and (ii) 'awareness' is consistently higher than 'use' in both interventions and crosssectional studies, although the relationship between the two outcomes is inconsistent.

Women who are least likely to take folic acid supplements are younger, on lower incomes and with lower educational levels, they are more likely to be single parents and/or belong to a minority ethnic group. Awareness of the recommendations for folic acid is lower in these groups than others. Only interventions specifically targeted at these groups were successful in increasing both awareness and use, although the baseline differential with women in other groups persists. If interventions do not target these vulnerable groups, awareness remains low and the differential in both awareness and use increases between these women and those who are less 'at risk'; that is, inequalities are exacerbated. The aspects of interventions which may increase effectiveness with vulnerable groups appear to be that: the women are 'sought out' and do not themselves have to be proactive; taking folic acid reflects what peers, friends and family are doing or saying; and the messages which are communicated are culturally and linguistically relevant, and emphasise the most confusing aspect of the message - that the supplements need to be taken before conception.

One of the original intentions of the present work was to identify when theoretical models had been used in interventions or evaluations. Descriptions of models of behavioural change are given, for example, in references (131), (134) and (135). In fact, only five such studies were identified in the main review. It is difficult to reach any conclusions based on this number of papers, but the social ecological model works at a number of different levels and many folic acid interventions appear to adopt it to some extent. The only model that was actively used, and with some success, was an adaptation of the Theory of Reasoned Action in the Dutch folic acid campaign.

Several important gaps in current knowledge emerged from the reviews. For example, data on trends in folic acid supplement intake in the UK were patchy, with different sets of data available and different methodologies used. Further research is needed into the potential effectiveness of:

1. Prescription of folic acid supplements to women in vulnerable groups, by general practitioners;

2. Provision of free folic acid supplements for all women below a specified age;

3. Interventions targeting vulnerable groups;

4. Comparing the acceptability of multivitamins (with $400 \mu \mathrm{g}$ folic acid) with folic acid only supplements;

5. Interventions based on the version of the Theory of Reasoned Action used in the Dutch folic acid campaign, or using other theoretical models.

In conclusion, realistically it is likely that efforts to increase supplement intake will have a limited effect. In The Netherlands, at the end of the Dutch folic acid campaign, $49 \%$ of the sample of pregnant women retrospectively reported taking folic acid during the time around conception ${ }^{(6)}$. In the UK, at the end of the national campaign, $38 \%$ of pregnant women, who were asked retrospectively, said they had taken folic acid supplements ${ }^{(64)}$. Extrapolating from these data could mean that high-quality and intensive national campaigns apparently influence under half of women in the target group to take supplements. However this figure is likely to be a considerable overestimate since data collected retrospectively from pregnant women give consistently higher values than data collected from samples of women of childbearing age in the population.

Reducing the number of unintended pregnancies in the UK would contribute to increasing the number of women taking folic acid supplements. Establishing a system for preconception care through general practice might also increase intake, if it was appropriately resourced and structured. However, these are major tasks that are unlikely to contribute to increasing usage of folic acid supplements 
in the UK in the short term. The present review highlights some findings which have the potential to contribute to an increase in uptake of folic acid supplements, but this is likely to be limited and continuing efforts would be needed for any increase to be sustained.

\section{Acknowledgements}

The present work was commissioned and supported by the Food Standards Agency. The authors particularly wish to thank Louis Levy and Alison Tedstone for their input, as well as the interviewees who provided in-depth information about the UK folic acid campaigns.

L.S. carried out the review and drafting; V.L. developed the framework and drafting.

\section{References}

1. MRC Vitamin Study Research Group (1991) Prevention of neural tube defects: results of the MRC Vitamin Study. Lancet 338, 131-137.

2. Czeizel AE \& Dudas I (1992) Prevention of the first occurrence of neural-tube defects by periconceptional vitamin supplementation. $N$ Engl J Med 327, 1832-1835.

3. Department of Health (1992) Folic Acid and the Prevention of Neural Tube Defects: Report from an Expert Advisory Committee. London: Department of Health.

4. Department of Health (2002) Folic Acid and the Prevention of Disease. Report on Health and Social Subjects no. 50. London: Department of Health.

5. Food Safety Authority of Ireland (2006) Report of the National Committee of Folic Acid Food Fortification. Dublin: Food Safety Authority of Ireland.

6. Food Standards Australia New Zealand (2004) Initial Assessment Report: Consideration of Mandatory Fortification with Folic Acid. Canberra/Wellington: FSANZ.

7. Food Standards Agency (2006) Folate and Health. London: FSA.

8. Dyson L, McCormick F \& Renfrew MJ (2005) Interventions for promoting the initiation of breastfeeding. Cochrane Database Syst Rev issue 2, CD001688.

9. Guise JM, Palda V, Westhoff C, Chan BK, Helfand M \& Lieu TA (2003) The effectiveness of primary care-based interventions to promote breastfeeding: evidence review and meta-analysis for the US Preventive Services Task Force. Ann Fam Med 1, 70-78.

10. Palda VA, Guise JM \& Wathen CN; Canadian Task Force on Preventive Health Care (2003) Interventions to Promote Breastfeeding: Updated Recommendations from the Canadian Task Force on Preventive Health Care, p. 15. London, Ontario: CTFPHC.

11. Fairbank L, O'Meara S, Renfrew MJ, Woolridge M, Sowden AJ \& Lister-Sharp D (2000) A systematic review to evaluate the effectiveness of interventions to promote the initiation of breastfeeding. Health Technol Assess 4, $1-171$.

12. Reid M \& Adamson H (1998) Opportunities for and Barriers to Good Nutritional Health in Women of Childbearing Age, Pregnant Women, Infants under 1, and Children aged 1-5. London: Health Education Authority.

13. Tedstone A, Dunce N, Aviles M, Shetty P \& Daniles L (1998) Effectiveness of Intervention to Promote Healthy
Feeding in Infants under One Year of Age: A Review. London: Health Development Agency.

14. Rowe RE, Garcia J, Macfarlane AJ \& Davidson LL (2002) Improving communication between health professionals and women in maternity care: a structured review. Health Expect 5, 63-83.

15. Ciliska D, Miles E, O'Brien MA, Turl C, Tomasik HH, Donovan U \& Beyers J (1999) Effectiveness of community based interventions to increase fruit and vegetable consumption. J Nutr Educ 32, 341-352.

16. Banks-Wallace J \& Conn V (2002) Interventions to promote physical activity among African American women. Public Health Nurs 19, 321-335.

17. Eden KB, Orleans CT, Mulrow CD, Pender NJ \& Teutsch SM (2002) Does counseling by clinicians improve physical activity? A summary of the evidence for the US Preventive Services Task Force. Ann Intern Med 137, 208-215.

18. Shepherd J, Garcia J, Oliver S, Harden A, Rees R, Brunton G \& Oakely A (2002) Barriers to, and Facilitators of, the Health of Young People, vols. 1 and 2. London: EPPI-Centre, Social Science Research Unit, Institute of Education, University of London.

19. Rees R, Harden A, Shepherd J, Brunton G, Oliver S \& Oakley A (2001) Young People and Physical Activity: A Systematic Review of Research on Barriers and Facilitators. London: EPPI-Centre, Social Science Research Unit, Institute of Education, University of London.

20. Dunn AL (1996) Getting started - a review of physical activity adoption studies. Br J Sports Med 30, 193-199.

21. Black ME, Yamada J \& Mann V (2002) A systematic literature review of the effectiveness of community-based strategies to increase cervical cancer screening. Can $J$ Public Health 93, 386-393.

22. Rowe RE, Garcia J \& Davidson LL (2004) Social and ethnic inequalities in the offer and uptake of prenatal screening and diagnosis in the UK: a systematic review. Public Health 118, 177-189.

23. Tseng DS, Cox E, Plane MB \& Hla KM (2001) Efficacy of patient letter reminders on cervical cancer screening: a meta-analysis. J Gen Intern Med 16, 563-568.

24. Forbes C, Jepson R \& Martin-Hirsch P (2002) Interventions targeted at women to encourage the uptake of cervical screening. Cochrane Database Syst Rev issue 3, CD002834.

25. Harden A, Brunton G, Fletcher A, Oakley A, Burchett H \& Backhams M (2006) Young People, Pregnancy and Social Exclusion: A Systematic Synthesis of Research Evidence to Identify Effective, Appropriate and Promising Approaches for Prevention and Support. London: EPPI-Centre, Social Science Research Unit, Institute of Education, University of London.

26. Kavanagh J, Trouton A, Oakley A \& Powell C (2006) A Systematic Review of the Evidence for Incentive Schemes to Encourage Positive Health and Other Social Behaviours in Young People. London: EPPI-Centre, Social Science Research Unit, Institute of Education, University of London.

27. Moos MK, Bartholomew NE \& Lohr KN (2003) Counseling in the clinical setting to prevent unintended pregnancy: an evidence-based research agenda. Contraception $\mathbf{6 7}$, 115-132.

28. Scottish Executive (2003) Enhancing Sexual Wellbeing in Scotland: A Sexual Health Relationship Strategy. Supporting Papers no. 5B and 5C. Edinburgh: Scottish Executive.

29. DiCenso A, Guyatt G, Willan A \& Griffith L (2002) Interventions to reduce unintended pregnancies among adolescents: systematic review of randomised controlled trials. BMJ 324, 1426. 
30. Akinbami LJ, Cheng TL \& Kornfeld D (2001) A review of teen-tot programs: comprehensive clinical care for young parents and their children. Adolescence 36, 381-393.

31. Harden A, Weston R \& Oakley A (1999) A Review of the Effectiveness and Appropriateness of Peer Delivered Health Promotion Interventions for Young People. London: EPPI-Centre, Social Science Research Unit, Institute of Education, University of London.

32. Saraiya M, Glanz K, Briss PA et al. (2004) Interventions to prevent skin cancer by reducing exposure to ultraviolet radiation: a systematic review. Am J Prev Med 27, 422-466.

33. Korenbrot CC, Steinberg A, Bender C \& Newberry S (2002) Preconception care: a systematic review. Matern Child Health J 6, 75-88.

34. Boulet SL, Parker C \& Atrash H (2006) Preconception care in international settings. Matern Child Health $J$ 10, 5 Suppl., S29-S35.

35. Public Health Agency of Canada (2000) Preconception care. In Family-Centred Maternity and Newborn Care: National Guidelines, Chapter 3. Ottawa: Public Health Agency of Canada.

36. American College of Obstetricians and Gynecologists (2005) ACOG Committee Opinion number 313, September 2005. The importance of preconception care in the continuum of women's health care. Obstet Gynecol 106, 665-666.

37. Johnson K, Posner SF, Biermann J, Cordero JF, Atrash HK, Parker CS, Boulet S \& Curtis MG; CDC/ATSDR Preconception Care Work Group; Select Panel on Preconception Care (2006) Recommendations to improve preconception health and health care - United States. A report of the CDC/ATSDR Preconception care work group and the Select Panel on Preconception Care. MMWR Recomm Rep 55, 123.

38. Moos MK, Bangdiwala SI, Meibohm AR \& Cefalo RC (1996) The impact of a preconceptional health promotion program on intendedness of pregnancy. Am J Perinatol 13, 103-108.

39. Czeizel AE (1999) Ten years of experience in periconceptional care. Eur J Obstet Gynecol Reprod Biol 84, 43-49.

40. Poppelaars FA, Cornel MC \& Ten Kate LP (2004) Current practice and future interest of GPs and prospective parents in pre-conception care in The Netherlands. Fam Pract 21, 307-309.

41. de Jong-Potjer LC, de Bock GH, Zaadstra BM, de Jong OR, Verloove-Vanhorick SP \& Springer MP (2003) Women's interest in GP-initiated pre-conception counselling in The Netherlands. Fam Pract 20, 142-146.

42. van Heesch PN, de Weerd S, Kotey S \& Steegers EA (2006) Dutch community midwives' views on preconception care. Midwifery 22, 120-124

43. Heyes T, Long S \& Mathers N (2004) Preconception care: practice and beliefs of primary care workers. Fam Pract 21, 22-27.

44. Jack BW, Culpepper L, Babcock J, Kogan MD \& Weismiller D (1998) Addressing preconception risks identified at the time of a negative pregnancy test. A randomized trial. J Fam Pract 47, 33-38.

45. Bernstein PS, Sanghvi T \& Merkatz IR (2000) Improving preconception care. J Reprod Med 45, 546-552.

46. Ray JG, Singh G \& Burrows RF (2004) Evidence for suboptimal use of periconceptional folic acid supplements globally. BJOG 111, 399-408.

47. Quinn LA, Thompson SJ \& Ott MK (2005) Application of the social ecological model in folic acid public health initiatives. J Obstet Gynecol Neonatal Nurs 34, 672-681.
48. Watson MJ, Watson LF, Bell RJ, Halliday JL, Burford N \& Brennecke SP (1999) A randomized community intervention trial to increase awareness and knowledge of the role of periconceptional folate in women of child-bearing age. Health Expect 2, 255-265.

49. Watson LF, Watson MJ, Halliday JL \& Bell RJ (2002) Consequences of surveying folate awareness. Health Expect 5, 38-46.

50. Lawrence JM, Watkins ML, Ershoff D, Petitti DB, Chiu V, Postlethwaite D \& Erickson JD (2003) Design and evaluation of interventions promoting periconceptional multivitamin use. Am J Prev Med 25, 17-24.

51. Robbins JM, Cleves MA, Collins HB, Andrews N, Smith LN \& Hobbs CA (2005) Randomized trial of a physicianbased intervention to increase the use of folic acid supplements among women. Am J Obstet Gynecol 192, 1126-1132

52. Watkins ML, Brustrom J \& Schulman J (2004) Effectiveness of a free folic acid supplement program in family planning clinics. Birth Defects Res A Clin Mol Teratol 70, 403-407.

53. Johnson PA, Stadler DD, Feldkamp M \& Webber B (2002) Impact of an educational seminar on high school students' knowledge of folic acid supplementation and its role in the prevention of birth defects. J Am Diet Assoc 102, 3 Suppl., S78-S81.

54. DiPietro NA \& Kier KL (2001) An educational intervention about folic acid and healthy pregnancies targeted at college-age women. J Am Pharm Assoc (Wash) 41, 283-285.

55. Quillin JM, Silberg J, Board P, Pratt L \& Bodurtha J (2000) College women's awareness and consumption of folic acid for the prevention of neural tube defects. Genet Med 2, 209-213.

56. Morgan C, Klein DA \& Selbst M (2004) Using CD-ROM technology to increase folic acid knowledge among physician assistant students. $J$ Allied Health 33, 194-199.

57. de Weerd S, Thomas CM, Cikot RJ, Steegers-Theunissen RP, de Boo TM \& Steegers EA (2002) Preconception counseling improves folate status of women planning pregnancy. Obstet Gynecol 99, 45-50.

58. Chacko MR, Anding R, Kozinetz CA, Grover JL \& Smith PB (2003) Neural tube defects: knowledge and preconceptional prevention practices in minority young women. Pediatrics 112, 536-542.

59. Edwards L \& Wyles D (1999) The folic acid message can training make a difference? J Hum Nutr Diet 12, 317-326.

60. Hauser KW, Lilly CM \& Frias JL (2004) Florida health care providers' knowledge of folic acid for the prevention of neural tube defects. South Med J 97, 437-439.

61. Williams P, McHenery J, McMahon A \& Anderson H (2001) Impact evaluation of a folate education campaign with and without the use of a health claim. Aust N Z J Public Health 25, 396-404.

62. Chan A, Pickering J, Haan E, Netting M, Burford A, Johnson A \& Keane RJ (2001) 'Folate before pregnancy': the impact on women and health professionals of a population-based health promotion campaign in South Australia. Med I Aust 174, 631-636.

63. Public Health Agency of Canada (2003) Evaluation of Food Fortification with Folic Acid for the Primary Prevention of Neural Tube Defects. Ottawa: Public Health Agency of Canada.

64. Raats M, Thorpe L, Hurren C \& Elliott K (1998) Changing Preconceptions, vol. 2. London: Health Education Authority.

65. van der Pal-de Bruin KM, de Walle HE, Jeeninga W, de Rover C, Cornel MC, de Jong-van den Berg LT, Schouten J, 
Brand R \& Buitendijk SE (2000) The Dutch 'Folic Acid Campaign' - have the goals been achieved? Paediatr Perinat Epidemiol 14, 111-117.

66. van der Pal-de Bruin KM, de Walle HE, de Rover CM, Jeeninga W, Cornel MC, de Jong-van den Berg LT, Buitendijk SE \& Paulussen TG (2003) Influence of educational level on determinants of folic acid use. Paediatr Perinat Epidemiol 17, 256-263.

67. de Walle HE, Cornel MC \& de Jong-van den Berg LT (2002) Three years after the Dutch folic acid campaign: growing socioeconomic differences. Prev Med 35, 65-69.

68. Egen V \& Hasford J (2003) Prevention of neural tube defects: effect of an intervention aimed at implementing the official recommendations. Soz Praventivmed $\mathbf{4 8}$, $24-32$

69. Centers for Disease Control and Prevention (1999) Folic acid campaign and evaluation - southwestern Virginia, 1997-1999. MMWR Morb Mortal Wkly Rep 48, 914-917.

70. Health Promotion Agency for Northern Ireland (1999) Public Awareness of Folic Acid in Northern Ireland. Belfast: Health Promotion Agency for Northern Ireland.

71. Watson LF, Brown SJ \& Davey MA (2006) Use of periconceptional folic acid supplements in Victoria and New South Wales, Australia. Aust N Z J Public Health 30, 42-49.

72. Bower C \& Stanley FJ (2004) Case for mandatory fortification of food with folate in Australia, for the prevention of neural tube defects. Birth Defects Res A Clin Mol Teratol 70, 842-843.

73. Bower C, Miller M, Payne J \& Serna P (2005) Promotion of folate for the prevention of neural tube defects: who benefits? Paediatr Perinat Epidemiol 19, 435-444.

74. Einarson A \& Koren G (2006) A survey of women's attitudes concerning healthy lifestyle changes prior to pregnancy. JFAS Int $\mathbf{4}$, e2.

75. French MR, Barr SI \& Levy-Milne R (2003) Folate intakes and awareness of folate to prevent neural tube defects: a survey of women living in Vancouver, Canada. J Am Diet Assoc 103, 181-185.

76. Morin P, De Wals P, Noiseux M, Niyonsenga T, St-CyrTribble D \& Tremblay C (2002) Pregnancy planning and folic acid supplement use: results from a survey in Quebec. Prev Med 35, 143-149.

77. Morin P, De Wals P, St-Cyr-Tribble D, Niyonsenga T \& Payette H (2002) Pregnancy planning: a determinant of folic acid supplements use for the primary prevention of neural tube defects. Can J Public Health 93, 259-263.

78. Morin VI, Mondor M \& Wilson RD (2001) Knowledge on periconceptional use of folic acid in women of British Columbia. Fetal Diagn Ther 16, 111-115.

79. Neimanis IM, Paterson JM \& Bain E (1999) Preventing neural tube defects. Survey of preconceptional use of folic acid. Can Fam Physician 45, 1717-1722.

80. Tam LE, McDonald SD, Wen SW, Smith GN, Windrim RC \& Walker MC (2005) A survey of preconceptional folic acid use in a group of Canadian women. J Obstet Gynaecol Can 27, 232-236.

81. Gjergja R, Stipoljev F, Hafner T, Tezak N \& LuzarStiffler V (2006) Knowledge and use of folic acid in Croatian pregnant women - a need for health care education initiative. Reprod Toxicol 21, 16-20.

82. Knudsen VK, Orozova-Bekkevold I, Rasmussen LB, Mikkelsen TB, Michaelsen KF \& Olsen SF (2004) Low compliance with recommendations on folic acid use in relation to pregnancy: is there a need for fortification? Public Health Nutr 7, 843-850.

83. McDonnell R, Johnson Z, Doyle A \& Sayers G (1999) Determinants of folic acid knowledge and use among antenatal women. J Public Health Med 21, $145-149$

84. Oleary M, Donnell RM \& Johnson H (2001) Folic acid and prevention of neural tube defects in 2000 improved awareness - low peri-conceptional uptake. Ir Med J 94 , 180-181.

85. Ward M, Hutton J, Mc Donnell R, Bachir N, Scallan E, O'Leary M, Hoey J, Doyle A, Delany V \& Sayers G (2004) Folic acid supplements to prevent neural tube defects: trends in East of Ireland 1996-2002. Ir Med J 97, 274-276.

86. Bakker MK, Cornel MC \& de Walle HE (2003) [Awareness and periconceptional use of folic acid among nonwestern and western women in the Netherlands following the 1995 publicity campaign]. Ned Tijdschr Geneeskd $\mathbf{1 4 7}$, 2426-2430.

87. de Jong-van den Berg LT, de Walle HE, van der Pal-de Bruin KM, Buitendijk SE \& Cornel MC (1998) Increasing awareness of and behaviour towards periconceptional folic acid consumption in The Netherlands from 1994 to 1995. Eur I Clin Pharmacol 54, 329-331.

88. Allen T, Thomson WM, Emmerton LM \& Poulton R (2000) Nutritional supplement use among 26-year-olds. $N Z$ Med J 113, 274-277.

89. Schader I \& Corwin P (1999) How many pregnant women in Christchurch are using folic acid supplements in early pregnancy? $N Z$ Med J 112, 463-465.

90. Braekke K \& Staff AC (2003) Periconceptional use of folic acid supplements in Oslo. Acta Obstet Gynecol Scand 82, 620-627.

91. Daltveit AK, Vollset SE, Lande B \& Oien H (2004) Changes in knowledge and attitudes of folate, and use of dietary supplements among women of reproductive age in Norway 1998-2000. Scand J Public Health 32, 264-271.

92. Vollset SE \& Lande B (2000) Knowledge and attitudes of folate, and use of dietary supplements among women of reproductive age in Norway 1998. Acta Obstet Gynecol Scand 79, 513-519.

93. Szumska A \& Mazur J (1999) [Evaluation of knowledge, attitudes and practice in healthy women of childbearing age concerning prophylactic folic acid - preliminary report]. Med Wieku Rozwoj 3, 509-520.

94. Cano-Serral G, Rodriguez-Sanz M, Borrell C, Perez Mdel M \& Salvador J (2006) [Socioeconomic inequalities in the provision and uptake of prenatal care]. Gac Sanit 20, $25-30$.

95. Coll O, Pisa S, Palacio M, Quinto L \& Cararach V (2004) Awareness of the use of folic acid to prevent neural tube defects in a Mediterranean area. Eur J Obstet Gynecol Reprod Biol 115, 173-177.

96. Garcia Carballo MM, Gonzalez Gonzalez AI \& Jimenez Garcia R (2003) [Prophylaxis of neural tube defects with folic acid in pregnant women from a health district]. Aten Primaria 31, 98-103.

97. Blake M, Herrick K \& Kelly Y (2003) Health Survey for England 2002: Maternal and Infant Health. London: The Stationery Office.

98. Glasgow Perinatal Effectiveness Committee (1998) Audit/ Re-audit of the Use of Folic Acid Supplements Preconception and in the First Trimester of Pregnancy. Glasgow: Glasgow Perinatal Effectiveness Committee.

99. Haslam C, Lawrence W \& Haefeli K (2003) Intention to breastfeed and other important health-related behaviour and beliefs during pregnancy. Fam Pract 20, 528-530.

100. Howell SR, Barnett AG \& Underwood MR (2001) The use of pre-conceptional folic acid as an indicator of uptake of a health message amongst white and Bangladeshi women in Tower Hamlets, east London. Fam Pract 18, 300-303.

101. ICM Research (2004) 1000 women aged 18+. Market research. London: ICM Research. 
102. Johnson K (2000) A study of nutritional knowledge and supplement use in pregnant women. J Hum Nutr Diet 13, 363.

103. Langley-Evans SC \& Langley-Evans AJ (2002) Use of folic acid supplements in the first trimester of pregnancy. $J R$ Soc Health 122, 181-186.

104. Mathews F, Yudkin P \& Neil A (1998) Folates in the periconceptional period: are women getting enough? $\mathrm{BrJ}$ Obstet Gynaecol 105, 954-959.

105. Neill AM, Laing RJ, Perez P \& Spencer PJ (1999) The 'Folic Acid Campaign': has the message got through? A questionnaire study. J Obstet Gynaecol 19, 22-25.

106. Relton CL, Hammal DM, Rankin J \& Parker L (2005) Folic acid supplementation and social deprivation. Public Health Nutr 8, 338-340.

107. Rogers I \& Emmett P (1998) Diet during pregnancy in a population of pregnant women in South West England. ALSPAC Study Team. Avon Longitudinal Study of Pregnancy and Childhood. Eur J Clin Nutr 52, 246-250.

108. Sen S, Manzoor A, Deviasumathy M \& Newton C (2001) Maternal knowledge, attitude and practice regarding folic acid intake during the periconceptional period. Public Health Nutr 4, 909-912.

109. Sillender M (2000) Continuing low uptake of periconceptional folate warrants increased food fortification. J Hum Nutr Diet 13, 425-431.

110. Sillender M \& Pring DW (2000) How effective was the Health Education Authority's folic acid campaign? J Obstet Gynaecol 20, 271-276.

111. Ahluwalia IB \& Daniel KL (2001) Are women with recent live births aware of the benefits of folic acid? $M M W R$ Recomm Rep 50, 3-14.

112. Alozie Arole CN, Puder KS, Reznar M, Eby E \& Zhu BP (2003) Folic acid awareness in Michigan, 1996-1999. Obstet Gynecol 102, 1046-1050.

113. Carmichael SL, Shaw GM, Yang W, Laurent C, Herring A, Royle MH \& Canfield M; National Birth Defects Prevention Study (2006) Correlates of intake of folic acid-containing supplements among pregnant women. Am J Obstet Gynecol 194, 203-210.

114. Centers for Disease Control and Prevention (1999) Knowledge and use of folic acid by women of childbearing age - United States, 1995 and 1998. MMWR Morb Mortal Wkly Rep 48, 325-327.

115. Centers for Disease Control and Prevention (2001) Knowledge and use of folic acid among women of reproductive age - Michigan, 1998. MMWR Morb Mortal Wkly Rep 50, 185-189.

116. Centers for Disease Control and Prevention (2004) Use of vitamins containing folic acid among women of childbearing age - United States, 2004. MMWR Morb Mortal Wkly Rep 53, 847-850.

117. Centers for Disease Control and Prevention (2005) Use of dietary supplements containing folic acid among women of childbearing age - United States, 2005. MMWR Morb Mortal Wkly Rep 54, 955-958.

118. Cleves MA, Hobbs CA, Collins HB, Andrews N, Smith LN \& Robbins JM (2004) Folic acid use by women receiving routine gynecologic care. Obstet Gynecol 103, 746-753.

119. de Jong-Van den Berg LT, Hernandez-Diaz S, Werler MM, Louik C \& Mitchell AA (2005) Trends and predictors of folic acid awareness and periconceptional use in pregnant women. Am J Obstet Gynecol 192, 121-128.

120. Goldberg BB, Alvarado S, Chavez C, Chen BH, Dick LM, Felix RJ, Kao KK \& Chambers CD; Teratogen Information Service (2006) Prevalence of periconceptional folic acid use and perceived barriers to the postgestation continuance of supplemental folic acid: survey results from a Teratogen Information Service. Birth Defects Res A Clin Mol Teratol 76, 193-199.

121. Hilton JJ (2002) Folic acid intake of young women. J Obstet Gynecol Neonatal Nurs 31, 172-177.

122. Kloeblen AS (1999) Folate knowledge, intake from fortified grain products, and periconceptional supplementation patterns of a sample of low-income pregnant women according to the Health Belief Model. J Am Diet Assoc 99, 33-38.

123. Kloeblen AS \& Batish SS (1999) Understanding the intention to permanently follow a high folate diet among a sample of low-income pregnant women according to the Health Belief Model. Health Educ Res 14, 327-338.

124. Perlow JH (2001) Comparative use and knowledge of preconceptional folic acid among Spanish- and Englishspeaking patient populations in Phoenix and Yuma, Arizona. Am J Obstet Gynecol 184, 1263-1266.

125. Rosenberg KD, Gelow JM \& Sandoval AP (2003) Pregnancy intendedness and the use of periconceptional folic acid. Pediatrics 111, 1142-1145.

126. Eurocat (2005) Prevention of Neural Tube Defects by Periconceptional Folic Acid Supplementation in Europe. Supported by the EU-Commission Public Health Directorate Programme of Community Action on Rare Diseases and WHO Collaborating Centre for the Epidemiology Surveillance of Congenital Anomalies. Northern Ireland: University of Ulster.

127. Health Education Authority (1999) Folic Acid Research Report. London: Health Education Authority.

128. Lynch SM (2002) Assessment of student pharmacists' knowledge concerning folic acid and prevention of birth defects demonstrates a need for further education. J Nutr 132, 439-442.

129. Power ML, Holzman GB \& Schulkin J (2000) Knowledge and clinical practice regarding folic acid among obstetrician-gynecologists. Obstet Gynecol 95, 895-898.

130. Lundqvist A, Wennberg AL, Lovgren $G$ \& Sandstrom $H$ (2004) [8 out of 10 midwives informed about folic acid. Most of them considered their knowledge about folic acid not sufficient]. Lakartidningen 101, 1380-1382, 1385-1386.

131. Roe L, Hunt P, Bradshaw H \& Rayner M (1997) Health Promotion Interventions to Promote Healthy Eating in the General Population; A Review. London: Health Education Authority.

132. Watson M, Watson L, Bell R \& Halliday J (2001) The increasing knowledge of the role of periconceptional folate in Victorian women of child-bearing age: follow-up of a randomised community intervention trial. Aust $N Z J$ Public Health 25, 389-395.

133. Freemantle N, Harvey EL, Wolf F, Grimshaw JM, Grilli R \& Bero LA (2000) Printed educational materials: effects on professional practice and health care outcomes. Cochrane Database Syst Rev issue 2, CD000172.

134. US Department of Health and Human Services (1996) Understanding and promoting physical activity. In US Surgeon General's Report on Physical Activity and Health, Chapter 6. Atlanta, GA: Centers for Disease Control and Prevention.

135. Institute for Social Marketing (2006) A Review of the Effectiveness of Social Marketing: Nutrition Interventions. NSMC Report no. 2. London: National Social Marketing Centre.

136. Folic Acid Action Roundtable (2004) Improving uptake and awareness of folic acid. http://www.microfolicacid. $\mathrm{com} / \mathrm{faa} /$ (accessed April 2008).

137. de Weerd S, Polder JJ, Cohen-Overbeek TE, Zimmermann LJ \& Steegers EA (2004) Preconception care: preliminary estimates of costs and effects of smoking cessation and folic acid supplementation. J Reprod Med 49, 338-344. 
Appendix - Databases, search terms and initial inclusion criteria for reviews

\section{Review 1}

The following databases were searched:

EPPI Centre

Health Technology Assessment databases (DARE, NHS EED, HTA)

National Electronic Library for Health - Cochrane databases

National Library for Health - Women's Health Specialist Library

PubMed (including Medline)

The following search terms were used in all of the databases above: women AND intervention AND (participation OR uptake) AND (systematic review OR meta analysis)

An additional search was undertaken in PubMed:

(systematic review OR meta analysis) AND (pre conception OR peri conception) OR (pre conceptual OR peri conceptual)

Studies were included if they were published systematic reviews and meta-analyses from Europe, the USA, Canada, Australia and New Zealand, for all dates in the electronic databases which were searched until May 2006, describing 'lifestyle' interventions to positively promote a specific health behaviour, with healthy free-living women of childbearing age.

\section{Review 2}

The following databases were searched:

EPPI Centre

National Library for Health - Women's Health Specialist Library

PubMed (including Medline)

ERIC

NELH

General Internet searches were also carried out using:

Google Scholar

Google

The following search terms were used in all of the databases above:

(preconception) OR (preconceptual)

Additionally, for the Internet searches:

NOT diabetes NOT gender

The review included published studies from Europe, the USA, Canada, Australia and New Zealand carried out in healthy, free-living women of childbearing age, specifically: (i) controlled trials included in the most recent relevant systematic review $^{(33)}$ identified in Review 1 (i.e. before June 1999); (ii) controlled trials carried out after the scope of the most recent relevant systematic review (i.e. June 1999-May 2006); (iii) in addition, more in-depth searches for published and unpublished work in the UK, dated June 1999-May 2006, were carried out.

\section{Review 3}

The following databases were searched:

EPPI Centre

Health Technology Assessment databases (DARE, NHS EED, HTA)

National Electronic Library for Health, including Cochrane databases

National Library for Health - Women's Health Specialist Library

PubMed (including Medline)

ERIC

General Internet searches were also carried out using:

Google Scholar

Google

Unpublished and grey literature was identified during Internet searches, and leads were provided during the course of the research. In addition, four in-depth interviews were carried out with individuals who were either: (i) experts/

workers in organisations committed to relevant areas of women's health; or (ii) were closely involved with the UK's folic acid campaign, either at a national or a local level.

Search terms included:

'folic acid' OR folate, AND supplements, AND uptake OR awareness, AND campaigns OR education, NOT homocysteine

The review included published quantitative and qualitative research from Europe, the USA, Canada, Australia and New Zealand, carried out from 1998 to May 2006, in healthy, free-living women of childbearing age. It also included in-depth searches for unpublished information on relevant experiences from European countries. Full-text translations of all included non-English material were sought. 